\title{
Degradation of Parachlorophenol by Electro-Fenton and Photo-Fenton Process Using Batch Recirculation Reactor
}

\author{
V. Manivasagan, ${ }^{a, *}$ C. Ahmed Basha, ${ }^{a}$ T. Kannadasan ${ }^{b}$ and K. Saranya $^{a}$ \\ ${ }^{a}$ Adhiyamaan college of Engineering, Hosur - 635 109, Tamilnadu, India \\ ${ }^{b}$ Coimbatore Institute of Technology, Coimbatore - 641 014, Tamilnadu, India
}

Received 28 September 2012; accepted 30 November 2012

\begin{abstract}
Chlorophenols are a group of special interest due to their high toxicity and low bio degradability. Advanced oxidation process constitutes a promising technology for the treatment of wastewaters containing non-easily removable organic compounds. Several electro chemical processes are based on mediated electro chemical oxidation. The present study envisages the utility of electro-fenton and photo-fenton process for the degradation of parachlorophenol from aqueous solution by the electro oxidation under acidic condition. Experiments were carried out under batch recirculation conditions with stainless steel as cathodes and $\mathrm{RuO} 2$ coated titanium expanded mesh as anodes. Electrolysis was carried out with various current densities and flow rate using mediated electro chemical oxidation process with fenton mediator $(\mathrm{Fe} 2+/ \mathrm{Fe} 3++\mathrm{H} 2 \mathrm{O} 2)$. Extent of dehydration and reduction in COD was studied as a function of applied current, electrolysis time and concentration of ferrous ion. The electrolysis was carried at optimised conditions to achieve efficiencies higher than $80 \%$.
\end{abstract}

Keywords: chlorophenols, electrolysis, Fenton mediator, degradation, wastewater.

\section{Introduction}

Human activities have contributed to the introduction of wide variety of synthetic organic compounds into the environment, and many are causing significant pollution of ground and surface waters; of all the organic pollutant causing problems around the world, the most harmful are aromatic hydrocarbons, chlorinated hydrocarbons and pesticides [1].

Although pesticides have been detected in water since the 1950's, in the last 15 years their use has risen dramatically all over the world and has nearly doubled every 5 years since 1975. On this way, chloro phenols(CPs) constitute a particular group of priority toxic pollutant listed by USEPA (environmental

\footnotetext{
*Corresponding author. E-mail: manivasaganv@gmail.com
} 
protection agency) in the clean water act [2-7] and by the European decision 2455/2001/EC [1,8-12], because most of them are toxic and hardly biodegradable and difficult to remove from environment. Various contaminations such as azo dyes, organo chlorine and dramatic hydrocarbons have been ducted, and a number of the chemical components are suspected of being endocrine disrupting chemicals (EDCs). Chlorophenols are introduced in the environment as a result of several man-made activities. Because of their broad-spectrum antimicrobial properties, CPs have been used as preservative agents for wood, paints, vegetable fibres and leather and as disinfectants [28-32]. In addition, they have been widely employed in many industrial processes as synthesis intermediates or as raw materials in the manufacture of herbicides, fungicides, pesticides, insecticides, pharmaceuticals and dyes. CPs may also be generated as by products during waste incineration and dechlorination of drinking water.

The presence of chlorophenols has been detected in both surface and ground waters as by products generation during waste incineration, the bleaching of pulp with chlorine, in the dechlorination of drinking water and as pesticides [27]. The electro-Fenton process can be recommended for the degradation of $p$ chlorophenol, when it is present in the medium at low concentrations.

The present work aims to study the degradation of P-chlorophenol (150 ppm) by first type of electro-Fenton process, which uses $\mathrm{Fe}^{2+}$ and $\mathrm{H}_{2} \mathrm{O}_{2}$, photo-assisted electro Fenton process, which uses Fenton's reagent and mercury lamp. The degradation of p-chlorophenol was studied by the following parameters [13-18]:

- to estimate the applicability of electro-Fenton and photo Fenton for degradation of $\mathrm{p}$-chlorophenol using batch recirculation reactor;

- to estimate the degradation of p-chlorophenol on different medium (sodium sulphate, sodium chloride, Fenton medium);

- to estimate the cod of the treated effluent at different time intervals and current densities;

- to estimate the variation in percentage absorption of chloride using spectroquant novac-60;

- to study the effect of flow rate on the removal of chloride ion and COD;

- to study the effect of current density on degradation of p-chlorophenol;

- to compare the degradation of p-chlorophenol by electro-Fenton and photoFenton method.

Compared to the conventional Fenton process, the electro-Fenton process has the advantage of allowing better control of the process and avoiding the storing and transport of the $\mathrm{H}_{2} \mathrm{O}_{2}$. Moreover, electricity as a clean energy source is used in the process, so the overall process does not create secondary pollutants. The utilization of photo-oxidative methods for the treatment of wastewaters offers several advantages, particularly the feasibility of total elimination of the organic pollutants. In spite of the proven efficiency of biological processes for the treatment of many types of wastewaters, they do exhibit limitations with respect to the range of concentration and toxicity of the pollutants. Photo-Fenton reaction can be driven with low energy photons in visible spectrum. Therefore, photo- 
Fenton process is a potential low cost treatment that can be run under solar light irradiation [20-27].

\section{Materials and methods \\ Experimental setup \\ Electro-Fenton process}

Experiments were carried out under galvanostatic condition at current density $1 \mathrm{~A} / \mathrm{dm}^{2}, 2 \mathrm{~A} / \mathrm{dm}^{2}$ and $3 \mathrm{~A} / \mathrm{dm}^{2}$ using $\mathrm{RuO}_{2}$ coated titanium expanded mesh anodes and stainless steel as cathodes. Synthetic effluent containing parachlorophenol $(150 \mathrm{ppm})$ is subjected to electrolysis in a batch recirculation reactor at fixed current density. Sodium sulphate solution $(0.05 \mathrm{M})$ was used as an electrolyte solution. The fluid flow circuit consists of a reservoir, a magnetically driven selfpriming centrifugal pump and an electrolytic cell. The electric circuit consists of a regulated DC power supply, ammeter and the cell with a voltmeter connected to the parallel to the reactor. The electrolyte was continuously stirred during the electrolysis using a magnetic stirrer. In order to generate the Fenton's reagent, the concentration of the mediator has been maintained at $0.25 \mathrm{~g} / \mathrm{L}$ and for the purpose of $\mathrm{OH}^{\circ}$ free radical, $\mathrm{H}_{2} \mathrm{O}_{2}$ was added at the rate of $1.5 \mathrm{~mL} / \mathrm{h}$. These experiments were carried out again in batch recirculation at different flow rates, namely 5,10,15,20 and $25 \mathrm{~mL} / \mathrm{min}$ (Tables $1-5$ ).

Table 1. Current density: $1 \mathrm{~A} / \mathrm{dm}^{2}$; time: $6 \mathrm{~h}$; current: $0.51 \mathrm{~A}$; mediator: $\mathrm{NaCl}$; reactor volume: $500 \mathrm{~mL}$.

\begin{tabular}{cccccc}
\hline Sl. No. & Flow rate & C.V. (Volts) & \multicolumn{2}{c}{ COD $(\mathbf{p p m})$} & \% COD reduction \\
& $(\mathbf{m L} / \mathbf{m i n})$ & & Initial & Final & \\
\hline 1 & 5 & $3.9-4.3$ & 980 & 530 & 45.91 \\
2 & 10 & $3.6-4.2$ & 960 & 470 & 51.04 \\
3 & 15 & $4.1-4.4$ & 860 & 430 & 50.02 \\
4 & 20 & $3.9-4.4$ & 920 & 560 & 39.13 \\
5 & 25 & $3.4-3.9$ & 880 & 620 & 29.54 \\
\hline
\end{tabular}

\section{Mechanism of degradation}

The degradation of parachlorophenol involves its dehydration and hydroxylation reactions with $\mathrm{OH}^{\circ}$. Hydroxyl radicals have strong oxidation capability and are responsible for oxidising various organic compounds. The attack of $\mathrm{OH}^{\circ}$ on Parachlorophenol could occur at ortho or meta or para positions which could produce 6-chloro-1,2 dihydroxy benzene or 6-chloro-1,3 dihydroxy benzene or 6chloro-1,4 dihydroxy benzene by the addition of $\mathrm{OH}^{\circ}$ in the respective position of parachlorophenol and abstraction of hydrogen atom from the corresponding position. These compounds upon further oxidation with loss of $\mathrm{Cl}^{-}$might yield a variety of intermediates. Stages of mechanisms include initial reaction, propagation, termination and parachlorophenol degradation.

$$
\begin{gathered}
\mathrm{CP}+\mathrm{H}_{2} \mathrm{O}_{2} \rightarrow \text { Intermediates }+\mathrm{H}_{2} \mathrm{O} \\
\mathrm{CP}+\mathrm{HO}^{\circ} \rightarrow \text { Intermediates } \\
\text { Intermediates }+\rightarrow \mathrm{CO}_{2}+\mathrm{H}_{2} \mathrm{O}+\mathrm{Cl}^{-} \\
\text {Intermediates }+\mathrm{H}_{2} \mathrm{O}_{2} \mathrm{HO}^{\circ} \rightarrow \mathrm{CO}_{2}+\mathrm{H}_{2} \mathrm{O}+\mathrm{Cl}^{-}
\end{gathered}
$$


Table 2. Current density: $1 \mathrm{~A} / \mathrm{dm}^{2}$; time: $6 \mathrm{~h}$; current: $0.51 \mathrm{~A}$; mediator: $\mathrm{Na}_{2} \mathrm{SO}_{4}$; reactor volume: $500 \mathrm{~mL}$.

\begin{tabular}{cccccc}
\hline Sl. No. & Flow rate & C.V. (Volts) & \multicolumn{2}{c}{ COD (ppm) } & \% COD reduction \\
& (mL/min) & & Initial & Final & \\
\hline 1 & 5 & $4.4-4.6$ & 970 & 490 & 49.48 \\
2 & 10 & $4.2-4.3$ & 940 & 370 & 60.63 \\
3 & 15 & $4.3-4.5$ & 920 & 310 & 66.04 \\
4 & 20 & $4.4-4.7$ & 980 & 440 & 55.10 \\
5 & 25 & $4.3-4.4$ & 890 & 460 & 48.31 \\
\hline
\end{tabular}

Table 3. Current density: $1 \mathrm{~A} / \mathrm{dm}^{2}$; Time: 6 h; current: $0.51 \mathrm{~A}$; mediator: $\mathrm{FeSO}_{4}+\mathrm{H}_{2} \mathrm{O}_{2}$; reactor volume: $500 \mathrm{~mL}$.

\begin{tabular}{cccccc}
\hline Sl. No. & Flow rate & C.V. (Volts) & \multicolumn{2}{c}{ COD $(\mathbf{p p m})$} & \% COD reduction \\
& $(\mathbf{m L} / \mathbf{m i n})$ & & Initial & Final & \\
\hline 1 & 5 & $4.1-4.4$ & 880 & 390 & 55.58 \\
2 & 10 & $4.4-4.6$ & 860 & 160 & 81.35 \\
3 & 15 & $3.7-3.8$ & 900 & 420 & 53.30 \\
4 & 20 & $3.7-3.9$ & 970 & 540 & 44.32 \\
5 & 25 & $3.5-3.7$ & 980 & 520 & 46.93 \\
\hline
\end{tabular}

\section{Photo-Fenton process}

Synthetic effluent containing parachlorophenol $(150 \mathrm{ppm})$ is subjected to electrolysis in a batch recirculation reactor at fixed current density $1 \mathrm{~A} / \mathrm{dm}^{2}$, $2 \mathrm{~A} / \mathrm{dm}^{2}$ and $3 \mathrm{~A} / \mathrm{dm}^{2}$ (Table 6). A continuous electrolysis was carried out at fixed current density in $0.05 \mathrm{M}$ sodium sulphate solution containing $\mathrm{H}_{2} \mathrm{O}_{2}$ and ferrous sulphate $(0.25 \mathrm{~g} / \mathrm{L})$. Similar to experimental conditions as electro-Fenton process, the photo-Fenton process requires low-pressure mercury vapour lamp for the generation of UV radiation supplied to parachlorophenol samples. Photo-Fenton process produces more hydroxyl radicals by the combination of $\mathrm{H} 2 \mathrm{O} 2$ vapour lamp and UV radiation with $\mathrm{Fe}(\mathrm{II})$ or $\mathrm{Fe}(\mathrm{III})$ oxalate ion.

Table 4. Current density: $2 \mathrm{~A} / \mathrm{dm}^{2}$; time: $6 \mathrm{~h}$; current: $0.98 \mathrm{~A}$; mediator: $\mathrm{FeSO}_{4}+\mathrm{H}_{2} \mathrm{O}_{2}$; reactor volume: $500 \mathrm{~mL}$.

\begin{tabular}{cccccc}
\hline Sl. No. & Flow rate & C.V. (Volts) & \multicolumn{2}{c}{ COD (ppm) } & \% COD reduction \\
& $(\mathbf{m L} / \mathbf{m i n})$ & & Initial & Final & \\
\hline 1 & 5 & $5.2-5.4$ & 920 & 530 & 42.39 \\
2 & 10 & $5.1-5.3$ & 700 & 180 & 74.28 \\
3 & 15 & $5.3-5.4$ & 720 & 160 & 77.77 \\
4 & 20 & $5.0-5.2$ & 900 & 400 & 55.56 \\
5 & 25 & $5.4-5.6$ & 920 & 510 & 44.56 \\
\hline
\end{tabular}

Table 5. Current density: $3 \mathrm{~A} / \mathrm{dm}^{2}$; time: $6 \mathrm{~h}$; current: $1.47 \mathrm{~A}$; mediator: $\mathrm{FeSO}_{4}+\mathrm{H}_{2} \mathrm{O}_{2}$; reactor volume: $500 \mathrm{~mL}$.

\begin{tabular}{cccccc}
\hline Sl. No. & Flow rate & C.V. (Volts) & \multicolumn{2}{c}{ COD (ppm) } & \% COD reduction \\
& $(\mathbf{m l} / \mathbf{m i n})$ & & Initial & Final & \\
\hline 1 & 5 & $6.1-6.3$ & 980 & 320 & 67.34 \\
2 & 10 & $6.1-6.4$ & 920 & 160 & 82.60 \\
3 & 15 & $6.4-6.7$ & 970 & 380 & 60.82 \\
4 & 20 & $5.9-6.1$ & 870 & 320 & 63.21 \\
5 & 25 & $6.1-6.2$ & 890 & 360 & 59.56 \\
\hline
\end{tabular}




\section{Mechanism of degradation}

Advanced oxidation process is based on the formation of $\mathrm{OH}^{\circ}$ radicals by means of the photolysis of the $\mathrm{H}_{2} \mathrm{O}_{2}$ and subsequent propagation of reaction. Degradation steps for parachlorophenol removal are the same as the ones exposed for reactions with Fenton's and $\mathrm{UV} / \mathrm{H}_{2} \mathrm{O}_{2}$ reagents. Nevertheless, another step for initial reactions must be added, which does not take place in Fenton's reaction, because there is no radiation

$$
\mathrm{H}_{2} \mathrm{O}_{2}+\mathrm{Fe}^{2+}+\mathrm{h} \gamma \rightarrow \mathrm{Fe}^{3+}+\mathrm{HO}^{-}+\mathrm{OH}^{\circ}
$$

The absorptivity of $\mathrm{H}_{2} \mathrm{O}_{2}$ may be increased by using UV lamps with output at lower wavelengths. Due to the additional generation of hydroxyl radical in the degradation of parachlorophenol by the Photo-Fenton reaction, the degree of degradation is higher compared to direct photolysis. The final products of degradation should be $\mathrm{CO}_{2}, \mathrm{H}_{2} \mathrm{O}$ and $\mathrm{Cl}^{-}$if complete mineralization is achieved.

\section{Analysis of COD}

COD of all samples were determined by the dichromate closed reflux method using a thermo reactor TR620-Merck. COD is generally considered as the oxygen equivalent to the amount of organic matter oxidizable by potassium dichromate. For COD analysis $1 \mathrm{~mL}$ of the sample was taken in COD tubes, and $2 \mathrm{~mL}$ of $0.25 \mathrm{~N} \mathrm{~K}_{2} \mathrm{Cr}_{2} \mathrm{O}_{7}$ and $3 \mathrm{~mL}$ of sulfuric acid were added to the sample. These tubes were kept in the thermo reactor for $20 \mathrm{~min}$. The organic matter of the sample was oxidized with a known excess of potassium dichromate in sulfuric acid solution. After $20 \mathrm{~min}$, the COD tubes were cooled. The excess dichromate was titrated against a standard solution of $0.1 \mathrm{~N}$ ferrous ammonium sulfate (FAS). COD value can be calculated as follows:

$$
C O D, m g L^{-1}=\frac{(\text { Blank titr e value }- \text { Sample titre value }) \times \text { Normality of } \mathrm{FAS} \times 8 \times 1000}{\mathrm{~mL} \text { of sample taken for estimation }}
$$

\begin{tabular}{|c|c|c|c|c|c|c|}
\hline \multirow{2}{*}{ Sl. No. } & \multirow{2}{*}{$\begin{array}{c}\text { Current Density } \\
\left(\mathbf{A} / \mathbf{d m}^{2}\right)\end{array}$} & \multirow{2}{*}{$\underset{\text { A }}{\text { Current }}$} & \multirow{2}{*}{$\begin{array}{c}\text { C.V. } \\
\text { (Volts) }\end{array}$} & \multicolumn{2}{|c|}{ COD (ppm) } & \multirow{2}{*}{$\%$ COD reduction } \\
\hline & & & & Initial & Final & \\
\hline 1 & 1 & 0.51 & $4.3-4.5$ & 960 & 160 & 83.34 \\
\hline 2 & 2 & 0.98 & $5.1-5.4$ & 880 & 240 & 72.72 \\
\hline 3 & 3 & 1.47 & $6.2-6.3$ & 930 & 220 & 76.34 \\
\hline
\end{tabular}

Table 6. Reactor volume: $500 \mathrm{~mL}$; time: $6 \mathrm{~h}$; mediator: $\mathrm{FeSO}_{4}+\mathrm{H}_{2} \mathrm{O}_{2}+\mathrm{h} \gamma$.

\section{Analytical method}

After sequential treatment, $20 \mathrm{~mL}$ of treated culture sample were subjected to various analytical methods. Biodegradation was analyzed by UV-Visible Spectrophotometer.

\section{UV-Vis Spectrophotometer analysis}

Samples were followed by monitoring changes in their absorption spectrum $(\lambda$ 360-700 nm); they were carried out using a Varian UV-Vis-NIR-500 Double Beam Spectrometer and comparing the result with the respective controls. A 
spectrophotometer was used together with a $1 \mathrm{~cm}$ optical path length to measure the UV spectra. A calibration graph was drawn by plotting absorbance against concentration (Tables 7 and 8).

\section{Results and discussion \\ Effect of pH}

At a $\mathrm{pH}$ above 4, the decomposition significantly decreases as $\mathrm{pH}$ increases, probably because the dissolved fraction of iron species decreases as colloidal ferric species appears. A second aspect of $\mathrm{pH}$ deals with its shift as the reaction progresses. The $\mathrm{pH}$ tends to decrease as ferrous ions as $\mathrm{FeSO}_{4}$ are added, because it typically continues residual $\mathrm{H}_{2} \mathrm{SO}_{4}$. On the other hand, it also tends to decrease as hydrogen peroxide is added and continues gradually at a rate, which is largely dependent on $\mathrm{Fe}^{2+}$ concentration, because CPs fragmentizes into organic acids.

\section{Table 7}

\begin{tabular}{cccccc}
\hline Sl. No. & Current A & C.V. (Volts) & Time (hr) & Absorbance & Chloride (ppm) \\
\hline 1 & 0.51 & 3.9 & 1 & 0.706 & 42.12 \\
2 & 0.51 & 4.0 & 2 & 0.762 & 63.97 \\
3 & 0.51 & 4.1 & 3 & 0.769 & 77.23 \\
4 & 0.51 & 4.2 & 4 & 0.813 & 83.86 \\
5 & 0.51 & 4.3 & 5 & 0.847 & 97.12 \\
6 & 0.51 & 4.3 & 6 & 0.852 & 99.07 \\
\hline
\end{tabular}

\section{Table 8}

\begin{tabular}{cccccc}
\hline Sl. No. & Current A & C.V. (Volts) & Time (hr) & Absorbance & Chloride (ppm) \\
\hline 1 & 0.51 & 4.3 & 1 & 0.689 & 41.73 \\
2 & 0.51 & 4.4 & 2 & 0.758 & 68.65 \\
3 & 0.51 & 4.5 & 3 & 0.798 & 84.25 \\
4 & 0.51 & 4.4 & 4 & 0.864 & 109.90 \\
5 & 0.51 & 4.5 & 5 & 0.902 & 125.60 \\
6 & 0.51 & 4.5 & 6 & 0.932 & 136.52 \\
\hline
\end{tabular}

\section{Effect of hydrogen peroxide concentration $\left(\mathrm{H}_{2} \mathrm{O}_{2}\right)$}

The concentration of hydrogen peroxide has an important influence in the degradation of CPs in order to push the reaction to final extent, i.e., $\mathrm{CO}_{2}$. The stoichiometric coefficient for the Fenton reaction has been found to be approximately $0.5 \mathrm{~mol}$ organic compound/mol $\mathrm{H}_{2} \mathrm{O}_{2}$. But for the purpose of generation of $\mathrm{OH}^{*}$ (free radicals) $\mathrm{H}_{2} \mathrm{O}_{2}$ was added at the rate of $0.1 \mathrm{~mL} / \mathrm{h}$, which results in steady reduction in COD (or) removal of chloride by degradation of $\mathrm{P}$ chlorophenol. The consumption of $\mathrm{OH}^{*}$ (free radical) degrades p-chlorophenols.

\section{Effect of catalytic ferrous ion concentration $\left(\mathrm{Fe}^{2+}\right)$}

The extent of degradation also depends upon ferrous concentration, since increase in ferrous ion concentration likely increases the generation of hydroxyl radicals, which is the major reactive species for the degradation of $p$ chlorophenol. The excess concentration of ferrous ion results in consumption of 
hydroxyl radicals according to the reaction and affects the extent of the degradation. Beside, the ferrous/ferric ions readily form stable complexes with $\mathrm{p}$ chlorophenol as per reaction. Hence it is preferable to use a limited concentration of ferrous ion $(0.25 \mathrm{~g} / \mathrm{L})$. Ferrous ions are utilized to degrade $\mathrm{p}$-chlorophenol.

\section{Effect of flow rate on cell voltage}

The characteristics of cell voltage vs. time at different current densities for degradation of p-chlorophenol in electro Fenton and photo Fenton processes are shown (Figs 1-4). The cell voltage variations with the inlet flow rate in all the current density are given in the tables. After continuous electrolysis, the optimum flow rate was found to be $10 \mathrm{~mL} / \mathrm{min}$.

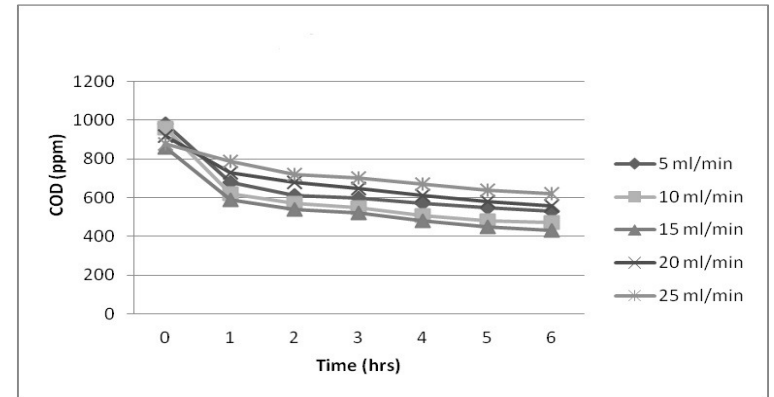

Figure 1. Electro oxidation with $\mathrm{NaCl}$.

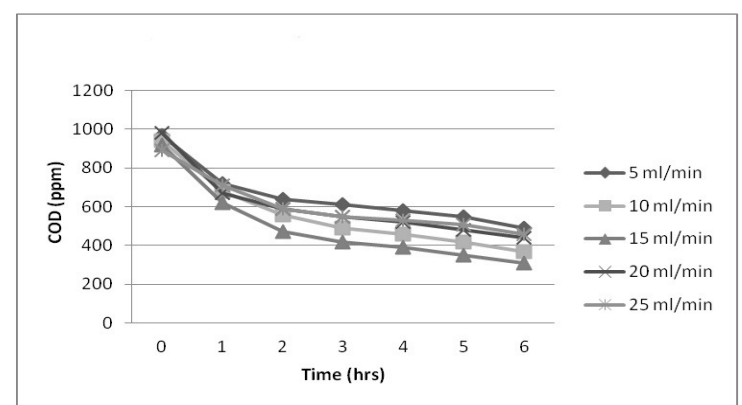

Figure 2. Electro oxidation with $\mathrm{Na}_{2} \mathrm{SO}_{4}$.

\section{Effect of flow rate on the rate constants}

The rate constant for the reaction of p-chlorophenols degradation for all the flow rate with various current densities are of the same order and are corresponding to the \% reduction of COD. The rate constant for the flow rate of $0.6 \mathrm{~L} / \mathrm{h}$ is the highest for the various current densities in electro-Fenton method as the \% reduction of COD is the highest for that flow rate.

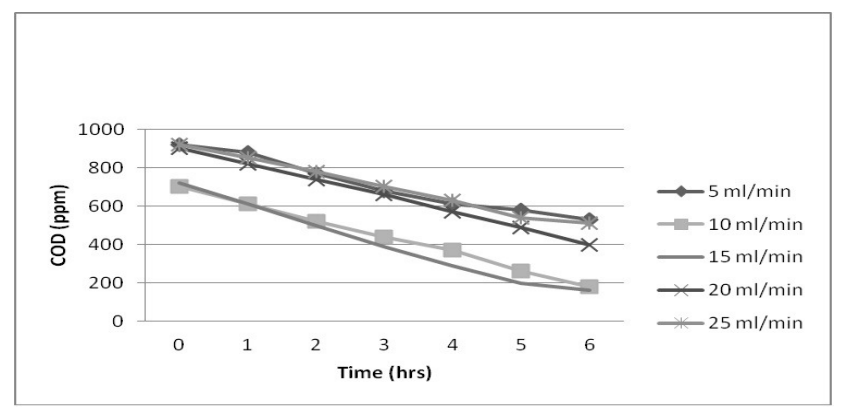

Figure 3. Electro oxidation with Electro - Fenton's medium. 


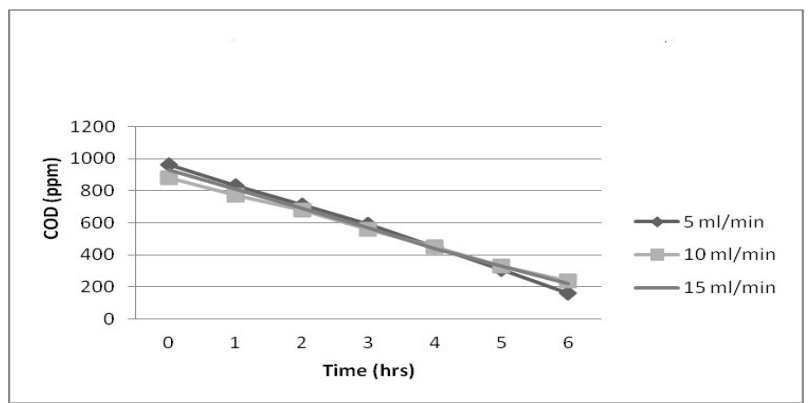

Figure 4. Electro oxidation with Photo - Fenton's medium.

\section{Conclusion}

From the study it can be concluded that electro-Fenton and photo-Fenton processes are highly useful in the degradation of p-chlorophenol from aqueous solution. It has been found that, the extent of degradation of p-chlorophenol is a function of the applied current, electrolysis time, concentration of p-chlorophenol and concentration of ferrous ion. The usage of electro-Fenton (or) photon-Fenton processes can be recommended for the degradation of p-chlorophenol at low concentrations, as the extent of degradation decreases when the concentration increases. The concentration of mediator was maintained at limited level in order to prevent the formation of stable complexes of ferrous ion with p-chlorophenol. Thus, from p-chlorophenol degradation result carboxylic acids as the major byproducts, which finally are mineralized to $\mathrm{CO}_{2}$.

\section{References}

1. Doble M, Kumar A. Biotreatment of industrial effluents. Elsevier, ButterworthHeinemann, 2005.

2. Gonçalves M, Alves MM, Correia JP, Marques IP. Bioresource Tech. 2008;99:8207-8211.

3. Gattrell D, Kirk K. J Chem Eng. 1990;68:997-1003.

4. Katsumata H, Koike S, Kaneco S, Suzuki T, Ohta K. J Environ Sci. 2010;22:1455-1461.

5. Hurst CJ, Sims RC, Sims JL, Sorensen DL, McLean JE, Huling S. J Agric Food Chem. 2005;53: 456-68.

6. Jianlong W, Yi N, Horn E, Stentiford E. Bioresource Tech. 2000;75:157-161.

7. $\quad$ Cheng-Chun J, Jia-Fa Z. J Zhejiang Univ Science A. 2007;8:1118-1125.

8. Jung MW, Ahn KH, Lee Y, Kim KP, Rhee JS, Park JT, Paeng KJ. Microchem. 2001;70:123-131.

9. $\quad$ Kuand Y, Wang LK. Ozone Sci Eng. 2002;24:133-144.

10. Lodato FO, Alfierib G, Olivieria A, Di Donato A, Marzochella A, Salatino P. Enzyme Microbial Tech. 2007;41:646-652.

11. Pera-Titus V, Garcia-Molina M, Banos MA, Gimenez J, Esplugas S. Appl Catal B: Environ. 2004;47:219-256.

12. Hessel C, Allegre C, Maisseu M, Charbit F, Moulin P. J Environ Manag. 2007;83:171-180. 
13. Bechtold T, Burtscher E, Hung YT. In: Waste Treatment in the Process Industries. Wang LK, Hung Y, Lo HH, Yapijakis C, editors. Boca Raton: CRC Press; 2006. P.363-398.

14. Robinson T, McMullan G, Marchant R, Nigam P. Bioresour Technol. 2001;77:247-255.

15. Cheremisinoff NP. Handbook of water and wastewater treatment technologies. Boston: Butterworth-Heinemann, 2002.

16. Brillas E, Cabot PL, Casado J. In: Chemical degradation methods for wastes and pollutants: environmental and industrial applications. Tarr MA, editor. New York: Marcel Dekker Inc., 2003. P. 1-70.

17. Georgiou D, Metallinou C, Aivasidis A, Voudrias E, Gimouhopoulos K. Biochem Eng J. 2004;19:75-79.

18. Georgiou D, Aivasidis A. J Hazar Mater B. 2006;135:372-377.

19. Mansour HB, Corroler D, Barillier D, Ghedira K, Chekir L, Mosrati R. Food Chem Toxicol. 2007;45:1670-1677.

20. Kalyani DC, Patil PS, Jadhav JP, Govindwar SP. Bioresour Technol. 2008;99:4635-4641.

21. Moutaouakkil A, Zeroual Y, Dzayri FZ, Talbi M, Lee K, Blaghenl M. Curr Microbiol. 2004;48:124-129.

22. Ali N, Hameed A, Ahmed S, Khan AG. World J Microbiol Biotechnol. In press. DOI: $10.1007 / \mathrm{s} 11274-007-9577-2$.

23. Parshetti GK, Kalme SD, Gomare SS, Govindwar SP. Bioresour Technol. 2007;98:3638-3642.

24. Adosinda M, Martins M, Ferreira IC, Santos IM, Queiroz MJ, Lima N. J Biotechnol. 2001;89:91-98.

25. Maximo C, Amorim MTP, Costa-Ferreira M. Enzyme Microb Technol 2003;32:145-151.

26. Blanquez P, Sarra M, Vicent T. Process Biochem. 2008;43:1-7.

27. S.T.Ambrosio, G.M. Campos-Takaki, Bioresour. Technol.91 (2004) 69-75.

28. Garcia-Montano J, Torrades F, Garcia-Hortal JA, Domenech X, Peral J. Appl Catal B. 2006;67:86-92.

29. Ledakowicz S, Solecka M, Zylla R. J Biotechnol. 2001;89:175-184.

30. Ghoreishi SM, Haghighi R. Chem Eng J. 2003;95:163-169.

31. Sudarjanto G, Keller-Lehmann B, Keller J. J Hazard Mat B. 2006;138:160-168.

32. Lucas MS, Dias AA, Sampaio A, Amaral C, Peres JA. Water Res. 2007;41:11031109. 